\title{
Mandenkan
}

MANDENIKAN Bulletin semestriel d'études linguistiques mandé

$65 \mid 2021$

Numéro 65

\section{Grammatical functions of tone in San Maka}

Fonctions grammaticales du ton en san maka

ЕЛЕНА ПЕРЕХВАЛЬСКАЯ. ГРАММАТИЧЕСКИЕ ФУНКЦИИ ТОНА В САН МАКА

\section{Elena Perekhvalskaya}

\section{(2) OpenEdition}

Journals

Electronic version

URL: https://journals.openedition.org/mandenkan/2574

DOI: 10.4000/mandenkan.2574

ISSN: 2104-371X

\section{Publisher}

Llacan UMR 8135 CNRS/Inalco

\section{Printed version}

Date of publication: 29 September 2021

Number of pages: 333-348

ISSN: 0752-5443

\section{Electronic reference}

Elena Perekhvalskaya, "Grammatical functions of tone in San Maka", Mandenkan [Online], 65 | 2021 Online since 29 September 2021, connection on 10 October 2021. URL: http://

journals.openedition.org/mandenkan/2574 ; DOI: https://doi.org/10.4000/mandenkan.2574

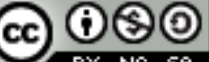

Les contenus de Mandenkan sont mis à disposition selon les termes de la Licence Creative Commons Attribution - Pas d'Utilisation Commerciale - Partage dans les Mêmes Conditions 4.0 International. 


\title{
Grammatical functions of tone in San Maka
}

\author{
Elena Perekhvalskaya \\ Institute for Linguistic Studies, Russian Academy of Sciences \\ elenap96@gmail.com
}

\section{Introduction ${ }^{1}$}

San Maka is a Mande language spoken in Burkina Faso. It is a language of the San/Samo language cluster. Together with Bisa, Busa/Boko/Bokobaru and Kyanga/Shanga language clusters, San/Samo form the Eastern group of the Mande language family. The main varieties of San/Samo are Maka in the South, Makya and Maya in the North; for more information see (Perekhvalskaya 2017a).

Most of the San Maka speakers, especially city residents, speak Moore (a language of the Gur family), which is the dominant language in this area and one of the languages of interethnic communication in Burkina Faso. It should be noted that for the northern dialects of San (San Maya and San Makya), the most pronounced is the influence of Jula, which began to displace the San languages in larger urban centers.

The phonology of San Maka, its tonal system included, was studied by Suzanne Platiel as a part of her doctoral dissertation (Platiel 1974). Moise Paré who did not specifically deal with the tonal system of San Maka in his articles, made several valuable comments regarding the grammatical meanings conveyed by tone (Paré 1998; Paré 1999).

\section{General information on the language}

Unlike the majority of Mande languages, San Maka does not display certain properties characteristic for isolating languages. The word order is strict: S Aux O V X; at the same time, the main word classes (noun, verb, pronoun) have a rich morphology. The level of fusion of morphemes is high in the verbal system and somewhat lower in pronouns and nouns. Nouns distinguish two morphophonological

${ }^{1}$ The study was supported by the Russian Science Foundation, grant 20-18-00250 "Tonal languages of the world: on-line data base and atlas". 
classes depending on the character of the final element (2.1.3.). Verbs can also be divided into several paradigmatic classes.

\subsection{Phonology}

\subsubsection{Vowels}

The system of vowels in San Maka is represented in Table 1.

Table 1. Vowel system of San Maka

\begin{tabular}{|l|c|c|c|}
\hline & Front & Middle & Back \\
\hline Closed & & $\eta$ & \\
\hline High & $i \tilde{\imath}$ & & $u \tilde{u}$ \\
\hline Mid-high & $e \tilde{e}$ & $\partial$ & $o \tilde{o}$ \\
\hline Mid-low & $\varepsilon \tilde{\varepsilon}$ & & $o \tilde{J}$ \\
\hline Low & & $a \tilde{a}$ & \\
\hline
\end{tabular}

Nasalization is a distinctive feature; the oral phoneme /o/ has no nasal counterparts. Phonetically long vowels are interpreted as combinations of two identical vowels; since the morpheme boundary can cut across such a long vowel: e.g., $m \bar{a} \bar{a}$ ' $m y$ ' $<m \bar{a} \bar{a}$ (1sg + POSs). Thus, words of the type $m \bar{a} \bar{a}$ ' $m y$ ' are considered disyllabic words, which is supported by the choice of the allomorph of the plural marker (see Table 4): only in disyllabic words does the plural marker $-\eta$ copy the tone of the last vowel (2.2.1.).

The phoneme $/ \mathrm{y} /$ is classified as a vowel on the following grounds: 1 ) it is a tonebearing unit; 2) its distribution is atypical for a consonant.

\subsubsection{Consonants}

Table 2. San Maka consonants

\begin{tabular}{|c|c|c|c|c|c|c|}
\hline \multirow{2}{*}{\multicolumn{2}{|c|}{\begin{tabular}{|l|} 
\\
Voiceless stops (plosives) \\
\end{tabular}}} & Labial & Dental & Palatal & Velar & Uvular \\
\hline & & $\mathrm{p}$ & $\mathrm{t}$ & $\mathrm{c}$ & $\mathrm{k}$ & \\
\hline \multicolumn{2}{|c|}{ Voiced stops } & b & d & $\mathrm{J}$ & $\mathrm{g}$ & \\
\hline \multicolumn{2}{|c|}{ Voiceless fricatives } & $\mathrm{f}$ & $\mathrm{s}$ & & & $\mathrm{h}$ \\
\hline \multicolumn{2}{|c|}{ Voiced fricatives } & & $\mathrm{z}$ & & & \\
\hline \multirow{3}{*}{ Sonorants } & Approximants & $\mathrm{w}$ & 1 & $\mathrm{y}$ & & \\
\hline & Vibrant & & $\mathrm{r}$ & & & \\
\hline & Nazals & $\mathrm{m}$ & $\mathrm{n}$ & $\mathrm{n}$ & & \\
\hline
\end{tabular}

The consonants $/ \mathrm{c} /$ and $/ \mathrm{y} /$ may be pronounced as affricates [t] and [d] or as palatal stops [c] and $[\mathrm{J}]$ respectively. Following San orthography, in this paper these sounds are spelled as $k i$ and $g i$, so, $k i o^{\eta 2}$ 'house' may be pronounced as [co] or [tfo].

${ }^{2}$ The final $\eta$ designates the floating nasal element (see below). 


\subsubsection{The floating (latent) final nasal ${ }^{\eta}$}

Some words in San Maka have a stem-final floating (latent) nasal which is normally not pronounced and does not nasalize the preceding syllable, cf.: bàá ${ }^{y}$ [bàá] 'bird' vs [bã்ấ] 'place'. ${ }^{3}$ The floating ${ }^{-\eta}$ is manifested through the choice of inflexion markers and postpositive auxiliaries (2.2.1.).

Thus, there are three phenomena connected with nasals apart from the phoneme $/ \mathrm{n} /:$ 1) nasalization of vowels; 2) nasal closed vowel $\eta$ which is a tone bearing unit; 3) the floating final nasal ${ }^{\eta}$.

In the practical writing, both the vowel $/ \mathrm{y} /$ and the floating final ${ }^{-\eta}$ are coded by the letter " $n$ " at the end of the word. This letter also denotes the consonant $/ n /$, but the latter does not occur at the end of the word; so, there is no distinction between the vowel $/ \mathrm{y} /$ and the floating final ${ }^{\boldsymbol{\eta}}$ in orthography. Nasalization is marked by the tilde (in a sequence of two vowels, only the second vowel is marked): baan [bàá] 'bird' vs baã [bã̃ấ] 'place'.

The final ${ }^{-\eta}$ occurs with nouns, adjectives and adverbs, but not with verbs. The presence/absence of the final nasal ${ }^{-\boldsymbol{y}}$ is the criterion for dividing nouns into two morphological classes. The form of some grammatical elements which follow an NP, such as the plural marker and some predicative markers, depends on the presence or absence of the final nasal element.

\subsubsection{Vowel harmony}

There is vowel harmony based on the vowel height: within one phonetic word, vowels can be either all mid-open $(o, \varepsilon)$ or mid-closed $(o, e)$. The rest of the vowels are neutral and can combine with the vowels of both harmonic rows: sèwò dà

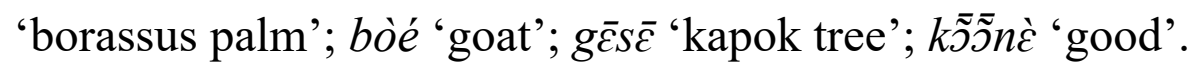

Table 3. Distribution of harmonic variants of elements $n A$

\begin{tabular}{|c|c|c|c|c|}
\hline & & Copula of identification & Postposition 'in' & Plural marker \\
\hline \multicolumn{5}{|c|}{ Left context } \\
\hline High & $i, u$ & $n \bar{\imath}$ & $n i$ & $n i$ \\
\hline \multirow{3}{*}{ Mid-high } & $e$ & \multirow{3}{*}{$n \bar{e}$} & \multirow{3}{*}{$n e ́$} & \multirow{3}{*}{ ná } \\
\hline & $\partial$ & & & \\
\hline & $o$ & & & \\
\hline \multirow[t]{2}{*}{ Mid-low } & $\varepsilon, \supset$ & \multirow{3}{*}{$n \bar{\varepsilon}$} & \multirow{3}{*}{$n \varepsilon \dot{~}$} & $n \varepsilon ́$ \\
\hline & o & & & $n \delta$ \\
\hline Low & $a$ & & & $n a ́$ \\
\hline
\end{tabular}

${ }^{3}$ Laura McPherson discussing latent nasals in Samogo writes: "Diachronically a nasal coda, these nasals often trigger alternations on the following consonant" (McPherson 2020: 68). The situation in San Maka seems similar. 
An important phonetic feature in San Maka is the existence of harmonic variants for two clitics and one bound morpheme. These are the copula of identification $n \bar{\varepsilon} / n \bar{e} / n \bar{l}$, a postposition $n \varepsilon$ ' $/ n e ́ / n i$ 'in, at', and the allomorphs of the plural marker appearing after the (-n) stems $-n \dot{l} /-n ə /-n \dot{\varepsilon} /-n \dot{ }$ /-ná. The distribution of the variants is shown in Table 3.

Examples. The copula of identification $|\mathrm{n} \overline{\mathrm{V}}|$ :
(1a) $M \bar{a}-\bar{a} \quad$ tásá $n \bar{\varepsilon}$.
1SG-POSS bowl COP
'It is my bowl'.

(1b) $M \bar{a}-\bar{a} \quad k i \bar{o}^{\eta} \quad n \bar{e}$.

$1 \mathrm{SG}-\mathrm{POSS}$ house COP

'It is my house'.
(1c) $M \bar{a}-\bar{a} \quad b \bar{u} \bar{u} k \bar{u} r u ̀ ~ n \bar{\imath}$.
$1 \mathrm{SG}-\mathrm{POSS}$ machete COP
'It is my machete'.

The postposition $|\mathrm{nV}|$ 'in, at': làydā né 'in tradition', nò né 'in the stomach', kíwí gólé né 'in the city (lit.: in big village)', wù bósò né 'in the preparation of tô ${ }^{4}$; pií ní 'in the market', wù ní 'in tô'.

Plural marker [nV́]: $s \bar{a} \dot{y}-n a ́$ 'the San people', $d \overline{\tilde{s}} \tilde{\partial}^{\eta}-n \delta$ 'relatives', $m \bar{\varepsilon}^{\eta}-n \varepsilon ́$ 'certain

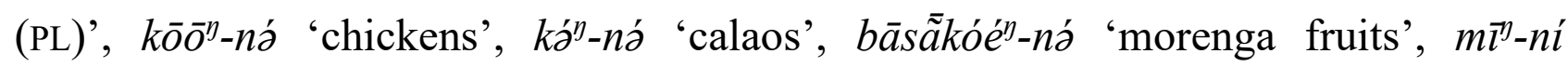
'people'.

\subsubsection{Tonal system}

San Maka is a tonal language with three level tones, designated, according to the IPA, by diacritics: acute (high), macron (mid) and grave (low). Vowel sequences may bear the following combinations of tones:

level cŕv́; c c̄̄ ; cv̀v̀

falling cŕv̀; cv́v̄; c̄̄̀̀

rising c̀̀vं; c̄v́v

Susanne Platiel focused on distribution of tonal units according to the types of syllables and words. She showed that words of the CVCV structure cannot carry the mid tone in both syllables if they contain closed or semi-closed vowels: /i/, /u/, /e/, /o/ (Platiel 1974: 132).

Platiel also pointed out the rarity of tonal minimal pairs and triplets: it is difficult to find three or four identical segment chains that would differ only by tone (Platiel

${ }^{4}$ Tô is a very common dish in Burkina Faso, consisting of cooked millet or sorghum flour. It is served as a paste and is eaten with a sauce. 
1974: 144). Here are some rare minimal pairs found in San Maka: pãa $\bar{a}$ 'gather' $\sim$ ã் 'cheek pà̃á 'force'; bálá 'individual field' bàlà 'stick'.

\subsection{Segmental morphology}

\subsubsection{Nouns}

Nouns in San Maka may belong to two morphonological classes: 1) ending with a vowel; 2) ending with the floating nasal ( $y$-nouns, see 2.1.3.). Consider the following pairs: $d \bar{a}$ 'fetish' vs. $d \bar{a}^{\eta}$ 'limit'; $d \jmath^{\prime}$ 'which also' vs $d \bar{j}^{\prime}$ 'pot'; $b a a^{\eta}$ 'bird' vs. $b \bar{a} \bar{a}$ 'run' vs bà̃áa' 'place', etc.

In San Maka, nouns and some determinants have a grammatical category of number. Plurality is marked on NPs consistently. The number is coded by the suffix $\eta / n a$, represented by several allomorphs. The choice of the allomorph depends on the paradigmatic class of the word. For $\eta$-nouns, the quality of the last vowel also matters (see 2.1.4.): the vowel is chosen depending on the final vowel of the noun stem. Other words form plurals by adding the suffix $-\eta$ which carries a high tone if the stem has the structure $\mathrm{CV}$; otherwise it acquires the tone of the previous syllable.

Table 4. The formation of nominal plural in San Maka

\begin{tabular}{|c|c|c|c|c|c|c|}
\hline \multicolumn{3}{|l|}{ Type of stem } & Singular & $\begin{array}{l}\text { Form of } \\
\text { plural } \\
\text { marker }\end{array}$ & Plural & Translation \\
\hline \multirow{7}{*}{$\begin{array}{l}\text { stems ending } \\
\text { with vowel }\end{array}$} & \multirow{3}{*}{\multicolumn{2}{|c|}{$\begin{array}{l}\text { one syllable } \\
\text { words }\end{array}$}} & só & $\dot{\eta}$ & sóń & 'tooth' \\
\hline & & & $t \grave{u}$ & $\dot{\eta}$ & tùñ & $\begin{array}{l}\text { 'well' (for } \\
\text { water) }\end{array}$ \\
\hline & & & 15 & $y^{\prime}$ & $l \bar{y} \dot{y}$ & 'woman' \\
\hline & \multirow{4}{*}{\multicolumn{2}{|c|}{$\begin{array}{l}\text { multisyllable } \\
\text { words }\end{array}$}} & sèré & $\dot{y}$ & sèréý & 'ram' \\
\hline & & & dذ̀m̄̄ & $\bar{\eta}$ & dذ̀m̄̄̄ & 'griot' \\
\hline & & & $g \overline{o ̀ o}$ & $\grave{\eta}$ & $g \overline{o ̀ o ̀ j}$ & 'liver' \\
\hline & & & wòtòró & $\dot{y}$ & wòtòróý & 'cart' \\
\hline \multirow[t]{7}{*}{ (y) stems } & \multirow[t]{7}{*}{ final vowel } & $a$ & $m \grave{a}^{\eta}$ & $n a ́$ & màná & 'thing' \\
\hline & & $\partial$ & $g j^{\eta}$ & nó & gónó & 'forest' \\
\hline & & $\varepsilon$ & $m \grave{\varepsilon}^{\eta}$ & $n \varepsilon ́$ & $m \dot{n} n \dot{~}$ & 'certain' \\
\hline & & $o$ & $k i \bar{o}^{\eta}$ & ná & kiōná & 'house' \\
\hline & & $e$ & $b \bar{a} s \overline{\bar{a}} k o e^{\eta}$ & ná & bāsã̄kóéná & $\begin{array}{l}\text { 'morenga } \\
\text { fruit' }\end{array}$ \\
\hline & & $\partial$ & $k \partial^{y}$ & ná & káná & 'calao' \\
\hline & & $i$ & $m \vec{\imath}^{\eta}$ & $n i ́$ & mini & 'person' \\
\hline
\end{tabular}

Nouns are subdivided into free and relational (inalienable) depending on their behavior in possessive nominal constructions. Free nouns require the possessive 
marker $\bar{a}$ : kii $\bar{a}$ kiō ${ }^{\eta}$ 'chief's house'. ${ }^{5}$ Relational nouns (terms for body parts, certain kinship terms) appear without this marker: kií gólógî̀ 'chief's elder brother'. Personal pronouns $2 \mathrm{SG}, 3 \mathrm{SG}$ and $3 \mathrm{PL}$ have no distinction between these two types of the possessive construction (see Table 5).

Table 5. Possessive pronouns with free and relational nouns in San Maka

\begin{tabular}{|c|c|c|c|c|c|}
\hline \multirow{2}{*}{ number } & \multirow[b]{2}{*}{ person } & \multicolumn{2}{|c|}{ free nouns } & \multicolumn{2}{|r|}{ relational nouns } \\
\hline & & & translation & & translation \\
\hline \multirow{3}{*}{ singular } & 1 & $m \bar{a} \bar{a} k i \bar{o}^{\eta}$ & 'my house' & $m \bar{a} d \bar{l}$ & 'my father' \\
\hline & 2 & $\overline{\boldsymbol{y}} \boldsymbol{k i} \overline{\boldsymbol{o}}^{\eta}$ & 'your house' & $\overline{\boldsymbol{y}} d \overline{\boldsymbol{\imath}}$ & 'your father' \\
\hline & 3 & $\grave{a} k_{i} \bar{o}^{y}$ & 'his/her house' & $\grave{a} d \bar{\imath}$ & 'his/her father' \\
\hline \multirow{3}{*}{ plural } & 1 & $w \bar{\partial} \bar{a} k i \bar{o}^{\eta}$ & 'our house' & $w \bar{\partial} d \bar{l}$ & 'our father' \\
\hline & 2 & $k \bar{a} \bar{a} k i \bar{o}^{\eta}$ & 'your (PL) house' & $k \bar{a} d \bar{\imath}$ & 'your (PL) father' \\
\hline & 3 & $\grave{j} \mathbf{k i} \overline{\boldsymbol{o}}^{\boldsymbol{y}}$ & 'their house' & $\grave{\eta} d \bar{\imath}$ & 'their father' \\
\hline
\end{tabular}

The bold characters point out forms which have no distinction in the possessive construction for free and relational nouns.

\subsubsection{Verbs}

Table 6. Morphological types of verbs in San Maka

\begin{tabular}{|c|c|c|c|c|c|}
\hline \multicolumn{2}{|c|}{ stem ending } & Neutral & Perfective & Imperfective & Translation \\
\hline \multirow{2}{*}{$-a$} & $\mathrm{Ca}$ & $g \bar{a}$ & $g \bar{a}$ & $g i \varepsilon$ & 'to look for' \\
\hline & $\mathrm{CVa}$ & $g \overline{\tilde{\tilde{\sigma}}} \overline{\tilde{a}}$ & $g \overline{\tilde{\sigma}} \dot{a}$ & $g \overline{\tilde{\sigma}} \overline{\tilde{\varepsilon}}$ & 'to stay' \\
\hline \multirow{2}{*}{$-\varepsilon$} & $\mathrm{C} \varepsilon$ & $d \bar{\varepsilon}$ & $d \bar{\varepsilon}$ & dii & 'to beat, to kill' \\
\hline & $\mathrm{CVC} \varepsilon$ & kذ̀ré & kذ̀rè & kìrè̀े & 'to cook' \\
\hline \multirow{2}{*}{ - } & $\mathrm{Co}$ & wó & wó & wóé & 'to enter' \\
\hline & CVCs & sòlś & sذ̀lo & sòlj̀c, sòlècે & 'to filter' \\
\hline$-e^{6}$ & $\mathrm{CvCe}$ & kérē & kérē & kérèè & 'to faint' \\
\hline$-O$ & CVCo & dórō & dōrò & dōròè, dōréè & 'to teach' \\
\hline \multirow{2}{*}{$-i$} & $\mathrm{Ci}$ & $m \bar{\imath}$ & $m \bar{\imath}$ & mií & 'to drink' \\
\hline & $\mathrm{CVi}$ & $b \bar{\imath}$ & $b \vec{\imath} \imath$ & $b \bar{\imath}$ & 'to eat' \\
\hline \multirow{2}{*}{$-u$} & $\mathrm{Cu}$ & $b \overline{\tilde{u}}$ & $b \dot{\tilde{u}}$ & $b \overline{\tilde{u} i}$ & 'to open' \\
\hline & $\mathrm{CVCu}$ & dúr $r \bar{u}$ & dūrù & dúrī & 'to hide' \\
\hline
\end{tabular}

In San Maka, a verbal lexeme has three morphological forms: neutral, perfective and imperfective. Based on the formation of the imperfective forms, Pare singles out

${ }^{5}$ When the possessor is in plural, the possessive marker is not used: kii $\eta$ kiō $\eta$ 'the chiefs' house'.

${ }^{6}$ No verbal stem of the CV structure ends on $-e$ and $-o$. 
7 types of verbs (Paré 1999: 38-41). However, if we take into account all characteristics, the actual number of paradigmatic classes of verbs in San Maka reaches at least 12 (see Table 6$)^{7}$

The neutral form is taken for basic in grammars and dictionaries (Platiel 1974; Paré 1999; Anonym 2003). It appears in non-indicative forms (imperative, hortative, jussive, conjunctive), as well as in the negative perfective (Kompaoré 2005). The perfective verb form is used with the affirmative predicative markers. The imperfective form appears in two affirmative and one negative imperfective construction; for details see (Perekhvalskaya 2017a; Perekhvalskaya 2017b).

Synchronically, the perfective is formed by a tone change (see Table 7).

Imperfective is formed through modification of both segmental and suprasegmental components; synchronically, it is fusional. Verbs of the CV structure get the CVV structure.

Apparently, the perfective and imperfective forms go back to non-finite forms (nominalizations, gerunds, etc.). This explains the fact that they cannot perform the predicative function on their own, and require the presence of a predicative marker. The perfective forms historically seem to have had a low tone suffix. The imperfective forms were formed by adding the suffix $-e /-\varepsilon$ which has fused with the stem. ${ }^{8}$ The neutral form, apparently, is a true verb by origin: it can appear in the predicative function without any additional marker; for more details see (Perekhvalskaya 2017a).

\section{Functions of tone}

\subsection{Lexical function of tone}

Tone in San Maka plays a role in both the lexicon and the grammar. There are minimal pairs which illustrate the function of tone in distinguishing lexical values.

$\begin{array}{ll}\text { bálá 'individual field' } & \text { bàlà 'stick'; } \\ \text { pà̃à 'cheek } & \text { pà̃à 'force'; } \\ \text { tóñ 'ashes' } & \text { tóý 'scorpion'; } \\ \bar{\eta} \text { 'you (SG)' } & \dot{y} \text { 'they'. }\end{array}$

Words belonging to different parts of speech:

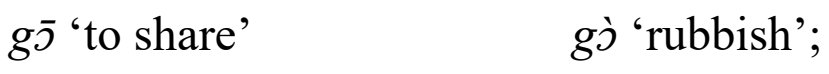

${ }^{7}$ The presented morphological classes cannot be boiled down just to phonological differences; the concrete forms are not completely predictable.

${ }^{8}$ The cognate of this suffix is attested in San Maya, a closely related language situated to the north of the San Maka territory. In San Maya the respective marker is a clitic which is never fused (Perekhvalskaya 2017b). 
kérēe 'to faint'

góró 'mortar'

gì̀lā 'stomach' kèrè 'shin';

gìrō 'already';

gìalà 'behind'.

It has to be noted that words which are homonyms in their basic forms may differ by their morphological behavior. Consider the following pair: the noun giz $\overline{\tilde{a}}$ 'wooden

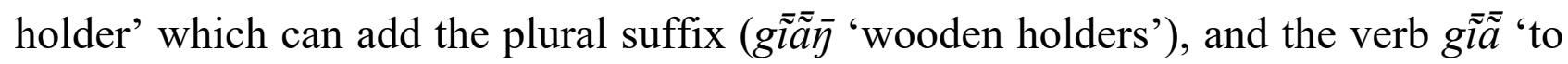

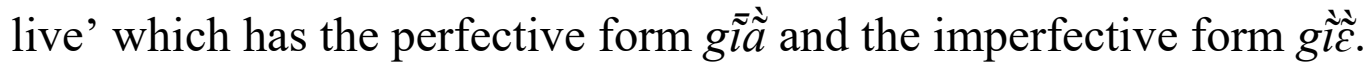

\subsection{Grammatical functions of tone}

In San Maka, tone has a wide range of grammatical meanings. The detailed investigation of the grammatical tone in Mande languages has been started by Maria Konoshenko (Konoshenko 2017). For tone and derivation, see also (Palancar \& Léonard 2016).

\subsubsection{The role of tone in the verbal morphology}

Tone is often the only distinctive feature that opposes neutral and perfective verbal forms, e.g., 'to come': $d \bar{a} \bar{a}$, neutral form vs. $d \bar{a} a ̀$ perfective (for more examples see Table 6).

The neutral verbal forms can have the following tonal and segmental structures:

cv: cv́, č̄, cv̀

cvv: $c v^{\prime} \bar{v}, c \bar{v} \bar{v}$

cvev: cúc̄̄, cv̀cŕ

evevv: $\operatorname{cv̀} \mathrm{C} \overline{\mathrm{V}} \overline{\mathrm{V}}$

Synchronically, the perfective is formed by a tone change:

Table 7. Tones in the neutral and perfective verbal forms

\begin{tabular}{|c|c|c|c|}
\hline Type & Neutral form & Perfective form & Example \\
\hline \multirow{3}{*}{$\mathrm{CV}$} & $\mathrm{H}$ & M & $k j$ 'to become' $>k \bar{j}$ \\
\hline & $\mathrm{M}$ & M & $d \bar{a}$ 'to put' $>d \bar{a}$ \\
\hline & $\mathrm{L}$ & $M$ & $w o ̀$ 'to go away' > wō \\
\hline \multirow{2}{*}{$\mathrm{CVV}$} & $\mathrm{HM}$ & ML & tó $\bar{a}$ 'to leave' > tōà \\
\hline & MM & ML & $k \overline{\tilde{l} \tilde{\varepsilon}}$ 'to write' $>k \tilde{\tilde{l}} \bar{\varepsilon}$ \\
\hline \multirow{2}{*}{ CVCV } & HM & ML & párē 'to jump' >pārè \\
\hline & LH & ML & sòl'́ 'to filter' > s̄̄lj̀ \\
\hline CVCVV & LMM & MML & kùrāō 'to hinder, impede' > kūrōò \\
\hline
\end{tabular}

The table 7 shows that the perfective is formed by similar tonal patterns: monosyllabic verbs acquire the mid tone; disyllabic and trisyllabic verbs display the ML or MML patterns. In fact, in perfective, all the verbs have the same tone melody 
$\mathrm{M}(\mathrm{L})$, but on a CV stem, there is no room to dock the L, and so only the $\mathrm{M}$ is realized. ${ }^{9}$

\subsection{Tone in derivation}

\subsubsection{Compound nouns}

In compound nouns, the tone of the second element rises: $\mathrm{L}>\mathrm{M}, \mathrm{M}>\mathrm{H}$.

$n \bar{\varepsilon}$ 'child' $+l \bar{\zeta}$ ' 'woman' $>n \bar{\varepsilon} l \bar{l}$ 'daughter';

$d \overline{l l}$ 'bull' $+n \bar{\varepsilon}$ 'child' $>d \bar{l} n n \varepsilon$ 'calf';

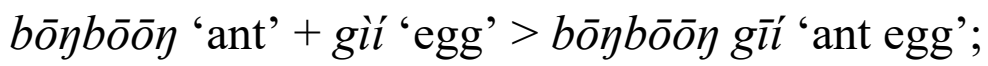

lón̄ 'sky' + bàa á 'bird' > lón̄ bāán 'avion'.

As it is not always possible to draw a line between compound words and genitive constructions of the type $\mathrm{N}+\mathrm{N}$, the exact status of some complex lexical items and the level of their grammaticalization is not always clear, ${ }^{10}$ see 3.4.1.

\subsubsection{Verb intransitivization}

San Maka displays verbal derivation by means of the tonal change. According to Paré, "This derivation process, which is very productive in the language, consists of creating new verbal bases from other verbal bases by a simple change of tone. It is generally applied on bases having the CV structure and involves high and medium tones" 11 (Paré 1998: 45). This intransitivization of an initially transitive verb by tone raising is quite productive: $\overline{\mathrm{V}}_{\mathrm{tr}}>\mathrm{V}_{\text {intr: }}$ :

transitive verb

$p \overline{\tilde{a}}$ 'to fill (smth)'

$l \overline{5}$ 'to crush'

$f \overline{\tilde{z}}$ 'to dig'

$j \bar{\varepsilon}$ 'to find'

$k \overline{\tilde{u}}$ 'to catch'

$b \bar{\jmath}$ 'to remove'

\section{intransitive verb}

$p \tilde{a}$ 'to be filled'

$l b$ 'to be crushed'

fo 'to dig oneself'

jé 'to be born'

$k \tilde{u}$ ' to be burned'12

bó 'to sprout'

${ }^{9}$ This analysis was proposed by an anonymous reviewer, I take this opportunity to thank her or him.

${ }^{10}$ On the definition of what is a word in isolating languages, see, for example (Idiatov 2005; Julien 2006).

${ }^{11}$ «Ce procédé de dérivation, très productif dans la langue, consiste à créer de nouvelles bases verbales à partir d'autres bases verbales par un simple changement de ton. Il s'applique généralement sur des bases ayant la structure CV et met en jeu le ton haut et moyen $»$.

${ }^{12}$ The same semantic shift is also registered in languages of the South Mande group, where this root displays a polysemy "to catch - to burn", see (Vydrin 2021: 155). 


\subsection{Tone in syntax}

\subsubsection{Genitive Construction}

The constructions of the type $\mathrm{N}+\mathrm{N}$ display the same proprieties as nominal compounds, see 3.3.1. The tone of the second component of the construction rises: $\mathrm{L}$ $>\mathrm{M} ; \mathrm{M}>\mathrm{H}$.

The nouns $n \bar{\varepsilon}$ 'child' and $l \bar{\nu}$ 'woman' in isolation both have mid tone. $l \bar{\nu}$ acquires a high tone in the compound $n \bar{\varepsilon} l$ ' 'girl', and this compound word receives a high tone as the second member of the genitive construction: sànná nél's 'a San girl'. The sequence sàyná nél'́ cannot be considered as a compound, because sàyná 'the San' is a plural form.

\subsubsection{Non-pronominal direct object}

Perfective and imperfective forms have similar tonal behavior: their tone is stable in any syntactic context. As for the neutral form, its tone raises in the presence of a direct object expressed by a full-fledged noun phrase. Consider the neutral form of the verb $b \overline{l l}$ 'to eat' in the imperative (3a, $3 \mathrm{~b})$ and conjunctive (3c) constructions with different types of the direct object. The neutral form of the verb $b \bar{\imath}$ 'to eat' carries a mid tone, but with the direct object expressed by a noun the tone of the verb becomes high. This tonal modification does not occur with the imperfective form of the same verb which retains its middle tone $(3 \mathrm{~d})^{13}$.
(3a) $\grave{\eta} \quad b \bar{\imath}$.
3PL eat
'Eat them!'
(3b) Kà wù bií.
2PL.IMP tô eat/H
'You (PL) eat tô'.

(3c) म́ pè mà Kōōdé wù bií.

$2 \mathrm{SG}$ say that Koode tô eat $/ \mathrm{H}$

'You ordered that Koodé would eat tô'.
(3d) $M \bar{a} \quad \bar{\eta} \quad w \grave{u} \quad b \bar{\imath}$.
1SG IPF tô eat.IPF
'I eat tô.'

Examples $(4 \mathrm{a}, 4 \mathrm{~b})$ demonstrate the tone raising $\mathrm{L}>\mathrm{M}$ under the same conditions (the verb $b \tilde{u}$ 'open'):

${ }^{13}$ This is reminiscent of tonal alternations in Seenku (McPherson 2019). 
(4a) Céylé bǜ!

door open

'Open the door!'

(4b)

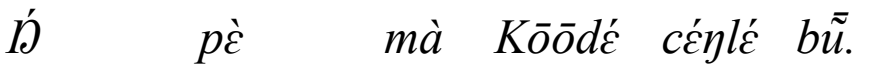
2SG.PFV say.PFV that Koode door open/M
'You ordered that Koodé would open the door'.

Disyllabic transitive verbs with the low tone on the first syllable (type cvev', see 3.2) change their tone to middle in the presence of a full-fledged direct object: cvicv́ $>$ č̄cv́. Consider the verb sìl's 'to filter':

(5) $M u ́ r \quad s \overline{l o ́}$

water filter/M

'Filter the water!'

\subsubsection{Pronominal 3SG direct object}

In the perfective construction, the pronominal 3SG object usually when referring to an inanimate object is often omitted. In this case, the tone of the verb lowers.

(6a) W' lōe $l \bar{e}$.

$1 \mathrm{PL} / \mathrm{H}$ song sing.PRF

'We sang a song'.

(6b) W' l’̀.

1 PL/H sing.PRF/L

'We sang it'.

(7a) W'́ pāā dūrù.

$1 \mathrm{PL} / \mathrm{H}$ money hide.PRF

'We hid the money'.

(7b) W'́ dùrù.

$1 \mathrm{PL} / \mathrm{H}$ hide.PRF/L

'We hid it'.

This is explained by the fact that the 3 sg pronoun $a$ bears the low tone, consider examples where this pronoun is presented (8):

(8) $\grave{A}$ kj̀ $m \bar{a} \quad l \bar{a}$.

$3 \mathrm{SG}$ give $1 \mathrm{SG}$ to

'Give it to me'. 
This tonal morpheme can therefore be regarded as an allomorph of a segmental morpheme $\grave{a}$ (for other cases of this type, see 3.5.) ${ }^{14}$.

\subsection{Tone as an allomorph of a segmental morpheme}

3.5.1. The affirmative perfective marker occupies the position after the subject

This morpheme has three allomorphs:

ná after $/ \mathrm{y} /$, see 2.1.3 (9);

màná when preceded by the plural marker (10);

high tone on the subject in other cases (11).

Examples:

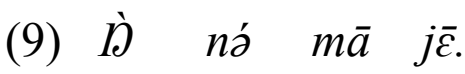

3PL PRF 1SG see.PRF

'They saw (have seen) me'.

(10) Gĩ்̃ góōy $\bar{a}$ dī- $\bar{\eta}$ màná wōò kàà mīa man one POSS bull-PL 3PL.PRF go.PRF fall.down.PRF neighbour

$\bar{\eta} \quad$ wùrú- $n$.

POSS field-in

'One man's bulls got into their neighbour's field'.

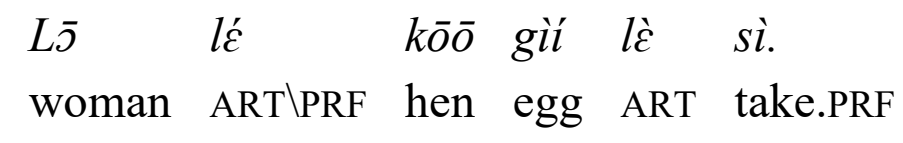

'The woman took the egg'.

In example (11) the perfective predicative marker is represented by the high tone of the article which defines the subject NP ( $l \bar{\zeta} l \grave{\varepsilon}$ 'the woman'); note that in the direct object NP kōō gì lè the article lè keeps its original tone.

In (12), the high tone as a perfective marker appears on the pronominal subject $m \bar{a}$ 'I, me':

$$
\begin{aligned}
& \text { Má wōò má dà̃à̀ } \bar{y} \quad \text { wùrú kj́s } \bar{y} \quad k a ́ \\
& \text { 1SG.PRF go.PRF 1SG.PRF in.law-PL POSS field cultivate/H COMIT }
\end{aligned}
$$

$z \grave{a} m \bar{a}^{\eta} \quad n \bar{\varepsilon}$.

crowd in

'I cultivated the field of my in-laws with the help of the association'.

A similar process manifests itself in postpositions: they acquire a low tone as an exponent of the 3 person singular pronoun $\grave{a}$ (animate or inanimate):

${ }^{14}$ I base this conclusion on the comparative dictionary of Mande languages (Vydrin ms.). 


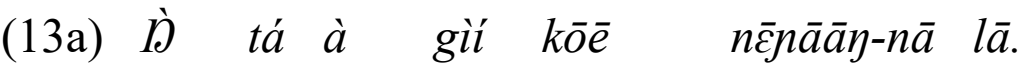

$3 \mathrm{PL}$ in $3 \mathrm{SG}$ egg give.IPF child-PL to

'They give these eggs to children'.

$\grave{n}$ ná bàsí dā, j̀ ná kj̀ là.

3PL PRF cuscus cook.PRF/M 3PL PRF give.PRF to/L

'They prepared cuscus and gave him'.

In the example (13a) the indirect object is expressed by the noun $n \bar{\varepsilon} n \bar{a} \bar{a} \eta-n \bar{a}$ 'children', the postposition $l \bar{a}$ 'to' has a mid tone; in the example (13b) the low tone of the postposition signals the presence of the 3 person pronoun '(to) him/her $/$ it'.

The 3sg pronoun $a ̀$ may be present as a segment unit, consider (14):
Bōyō gõ̃a $\bar{\eta}$ búsì
à gíálá tón
$n \bar{a} \quad \dot{a}$
$s \bar{\gamma}-\bar{y}$

Boyo foot IPF hurt.IPF because scorpion TOP 3SG.PRF tooth-PL

d’̀ $\quad \grave{a} \quad \bar{a}$.

build.PRF $3 \mathrm{SG}$ on

'Boyo's foot hurts as a scorpion has bitten him/it'.

The choice between the segment pronoun $\grave{a}$ or its tonal allomorph depends, as it seems, on the pragmatic status of the participant; in (14) the bitten foot of Boyo is the focus of attention of the speaker.

\section{Discussion and conclusion}

The presented material shows that, apart from the distinguishing lexical values of words, tone in San Maka expresses many grammatical meanings.

This function is most clearly distinctive in the verbal paradigms; in San Maka, the verb exists in three morphological forms: neutral, perfective and imperfective. In many cases, the perfective form differs from the neutral one only by its tonal characteristics. At the same time, I would like to note that this function of tone is rather pronounced in verb systems of many Mande languages.

In certain cases, tonal allomorphs coexist with segmental ones. There are two such cases in San Maka. The first is the low-tone unit encoding the presence of a pronominal inanimate direct object (see 2.4.3.). In fact, in this case, the low-tone unit is an allomorph of the 3rd person pronoun. The second case it the perfective predicative marker, whose tonal allomorph is the most frequent exponent. However, in both cases, since tonal allomorphs have segmental counterparts, they should not be considered "floating tones" in strict sense. The canonical floating tone is expressed 
through downstep (or upstep?) ${ }^{15}$ and is singled out through interpretation; it does not alternate with segmental units. ${ }^{16}$

The surface tonal representation consists of the combination of many factors: initial tonal characteristics of lexemes are modified under the influence of tonal morphemes and then combine with grammatical tones.

\section{Abbreviations}

$$
\begin{aligned}
& 1,2,3-1,2,3 \text { person } \\
& \text { ART - article } \\
& \text { COMIT - comitative } \\
& \text { COP - copula } \\
& \mathrm{H}-\text { high tone } \\
& \text { IPF - imperfective }
\end{aligned}
$$

$$
\begin{aligned}
& \text { L - low tone } \\
& \text { PL - plural } \\
& \text { POSS - possessive preposition } \\
& \text { PRF - perfective } \\
& \text { SG - singular. }
\end{aligned}
$$

\section{References}

Anonym. 2003. Boo nen séwe san-fransi, fransi-san [Lexique san-français, français-san]. Ouagadougou: Société internationale de linguistique.

Idiatov, Dmitry. 2005. La détermination des limites de mots: l'exemple de l'orthographe toura. Mandenkan 41. 29-39.

Julien, M. 2006. Word. Encyclopedia of languages and linguistics. Elsevier.

Kompaoré, Garber A. 2005. Problèmes de perturbations tonales et l'orthographe san. SIL.

Konoshenko, Maria. 2017. Tone in grammar: What we already know and what we still don't? Voprosy Jazykoznanija (4). 101-114.

McPherson, Laura. 2019. Seenku argument-head tone sandhi: Allomorph selection in a cyclic grammar. Glossa 4.1(22). https://doi.org/10.5334/gjgl.798.

McPherson, Laura. 2020. On latent nasals in Samogo. Mandenkan 63. 68-88. https://doi.org/10.4000/mandenkan.2314.

Palancar, Enrique L. \& Jean Léo Léonard. 2016. Tone and inflection: An introduction. In Tone and Inflection: New Facts and New Perspectives (Trends in Linguistics Studies and Monographs 296), 1-11. Berlin, Boston: De Gruyter Mouton.

Paré, Moïse. 1998. L'énoncé verbal en san (parler de Yaba). Ouagadougou: Université de Ouagadougou M.A.Thesis.

${ }^{15}$ See (Vydrin 2016).

${ }^{16}$ In a wider sense, the term "floating tone" may be applied to the tonal allomorph of a segmental morpheme and be regarded as a tone morpheme that does not have a segmental host. In some languages, it might trigger downstep, but in others, it may concatenate with lexical tones, or replace them (I thank an anonymous reviewer for this remark). 
Paré, Moïse. 1999. Dérivation, composition et syntagmes nominaux en san (parler de Yaba). Ouagadougou: Université d'Ouagadougou Rapport de D.E.A.

Perekhvalskaya, Elena. 2017a. Basic morphosyntax of verbal and non-verbal clauses in San Maka. Mandenkan 57. 49-76. https://doi.org/10.4000/mandenkan.1070.

Perekhvalskaya, Elena. 2017b. Aspektual'naja sistema juzhnogo san (san-maka) v diakhronicheskoj perspektive (Аспектуальная система южного сан (сан-мака) в диахронической перспективе) [The aspectual system of Southern San (San Maka): Diachronic perspective]. In Alexander Ju. Zheltov (ed.), African Collection 2017, 433448. St. Petersburg: Kunstkamera.

Platiel, Suzanne. 1974. Description du parler samo de Toma, Haute-Volta. Phonologie, syntaxe. Paris: Université René Descartes Doctorat d'État.

Vydrin, Valentin. 2016. Tonal inflection in Mande languages: The cases of Bamana and Dan-Gwectaa. In Enrique L. Palancar \& Jean Léo Léonard (eds.), Tone and Inflection: New facts and new perspectives (Trends in Linguistics Studies and Monographs 296), 83-105. De Gruyter - Mouton.

Vydrin, Valentin. 2021. Dictionnaire dan de l'Est-français suivi d'un index français-dan. Mandenkan 65. 3-332. https://doi.org/10.4000/mandenkan.2541.

Vydrin, Valentin. Etymological dictionary of Mande family. Ms.

\section{Elena Perekhvalskaya}

\section{Grammatical functions of tone in San Maka}

The paper is an overview of the functions of tone in San Maka (Eastern Mande < Mande $<$ Niger-Congo). In this language, tone has different grammatical functions in addition to distinguishing lexical meanings of words. The analysis of tone shows that its grammatical functions embrace different morpho-syntactic domains. Tonal oppositions are analyzed in the wide contexts of segmental morphology of the language. It is shown that tonal oppositions may distinguish paradigmatic word forms, which is primarily characteristic of a verb; tone is often the only distinctive feature that opposes neutral and perfective verbal forms. San Maka also displays verbal derivation by means of the tonal change. Tone oppositions are used in genitive constructions of the type $\mathrm{N}+\mathrm{N}$, where the tone of the second component rises.

A special section is devoted to so-called floating tones. In San Maka, floating tones are allomorphs of segmental units: the $3 \mathrm{sg}$ pronoun $\grave{a}$ and the perfective predicative marker $n$ ó, in certain contexts, are realized as tones.

Key words: San-Maka, Eastern Mande, Mande, grammatical tone, floating tone 


\section{Елена Перехвальская}

\section{Грамматические функции тона в сан мака}

Статья представляет собой обзор функций тона в сан-мака (восточные манде $<$ манде $<$ нигер-конго). В этом языке помимо различения лексических значений слов тон выполняет различные грамматические функции. Анализ показывает, что его грамматические функции охватывают разные морфосинтаксические области. Показано, что тональные противопоставления служат образованию словоформ в парадигме, что, в первую очередь, характерно для глагола; тон часто является единственным дистинктивным признаком, противопоставляющим исходную (нейтральную) и перфективную формы глагола. Сан-мака демонстрирует случаи глагольной деривации посредством изменения тона. Тональные оппозиции используются также в генитивных конструкциях типа $\mathrm{N}+\mathrm{N}$, где тон второго компонента повышается.

Отдельный раздел посвящен так называемым плавающим тонам. В сан-мака плавающие тоны являются алломорфами сегментных единиц: местоимение 3 л. ед. ч. $\grave{a}$ и предикативный маркер nд́ в определенных контекстах реализуются как тоны.

Ключевые слова: сан-мака, восточная группа манде, грамматический тон, плавающий тон

\section{Elena Perekhvalskaya}

\section{Fonctions grammaticales du ton en san maka}

L'article traite des fonctions du ton en san-maka (Mandé-Est $<$ Mandé $<$ NigerCongo). Dans cette langue, en plus de distinguer les sens lexicaux des mots, le ton remplit diverses fonctions grammaticales. Une analyse des usages du ton montre que ses fonctions recouvrent différents domaines morpho-syntaxiques. Les oppositions tonales sont analysées dans le contexte large de la morphologie segmentale de la langue. On montre que les oppositions tonales servent à la formation des formes des mots dans le paradigme, ce qui est caractéristique surtout du verbe ; le ton est souvent le seul trait distinctif qui s'oppose la forme neutre et la forme perfective du verbe. En san-maka la dérivation verbale peut être effectuée par le changement du ton. Les oppositions tonales sont utilisées dans les constructions génitives $\mathrm{N}+\mathrm{N}$ où le ton de la deuxième composante se relève.

Une section est consacrée aux tons flottants. En san-maka, les tons flottants sont des allomorphes d'unités segmentales : dans certains contextes, le pronom de 3 personne $a ̀$ et le marqueur prédicatif ná peuvent être réalisés comme le chagement du ton.

Mots clés : san-maka, Mandé-Est, Mandé, ton grammatical, ton flottant 